\title{
THE FIRST GENERATION'S TACIT KNOWLEDGE TRANSFER
}

\author{
Teddy Saputra \\ Department School of Entrepreneurship, Family Business Center, \\ Universitas Ciputra, Surabaya, Indonesia
}

\begin{abstract}
This study aims to see and learn when, how and what are the transfer of tacit knowledge between the senior generation and the next generation of first generation family companies in Surabaya. This is qualitative research. The study found that the transfer of tacit knowledge was planned and initiated by the senior generation. Transfers are carried out by observation, experiencing and reflection methods where unique senior generation knowledge such as trust in certain value values is transferred to the next generation which is then studied by the next generation to become a separate value.
\end{abstract}

Keywords: family business, senior generation, next generation, tacit knowledge, knowledge transfer

\section{INTRODUCTION}

A lot of young business people are reluctant to become the successors of their family companies. They argue that their involvement in family companies is vulnerable to conflicts that threaten relationships within the family. Regardless of these reluctant young people, it is clear that family companies are one of the most common practices of corporate organization in the world. Nearly all companies start their business activities from family companies (Lee, 2006).

Unlike ordinary companies, family companies are unique in their management. Gersick (1997) explains that family companies are special organizations. Some research has found that in the uniqueness of the family business system is the involvement and preparation process carried out by the next generation (Frank et al., 2010; Wayne et al., 2010; Zellweger et al., 2010): knowledge transfer that has been considered a process that happens by itself (Trevinyo-Rodriguez \& Tapies, 2006). Only 30\% of family companies can survive a transition period between generations of the first to second generation as indicated by the Family Firm institute for The Family Business review (Hall et al., 2008). Only $12 \%$ of family companies survive in the second and third generation periods and this situation shows the problems that occur in generation preparation.

Trevinyo-Rodriguez \& Tapies (2006) explains that the transition in family companies includes entrusting power, managerial responsibility and competence to the next generation, and this process is called the succession process. Most family companies are not ready to plan the succession process. As a result, it causes problems threatening the sustainability of the family company (Lambrecht, 2005). Fox et al. (1996), explained the causes of succession failure: most family companies did not pay

\footnotetext{
*Corresponding Author.

e-mail: teddy.saputra@ciputra.ac.id
} 
Teddy Saputra / The First Generation's Tacit Knowledge Transfer /

JEE, Vol. 7, No. 2, September 2018, pp 95-104

attention to this when the company's founder was still alive.

One important process in preparing for succession is the transfer of knowledge from the company's founder to the next generation. The same knowledge forms the same understanding of the family company (Chirico, 2008), and the same understanding helps the succession process.

Davenport \& Prusak (1998) explains that knowledge is a frame of mind that is composed of experience, values, contextual information and comes from expert opinion. Knowledge is then used for evaluation when dealing with new information. Weggeman (1997) explains that knowledge is a product of someone's information, experience, skills and attitudes. Gardner (1995) explains that knowledge is, (1) knowing what is needed (Knowing what), (2) knowing how information can be processed (Knowing how), (3) knowing why information is needed (Know why), (4) knowing where information can be obtained to get specific results (Know where), and (5) knowing when that information is needed (Knowing when)". Polanyi (1966) who is known as the father of knowledge divides two types of knowledge, namely categories (1) "Knowing" and categories (2) "Knowledge". Knowing is a category of knowledge that is related to the skills to do something that is generally difficult to explain to others regarding why and how to do something. Polanyi (1966) gave an example of riding a bicycle where many people could do it but it was difficult to explain the process of riding a bicycle to someone else. Knowledge of "knowing" is called tacit knowledge (Nonaka \& Takeuchi, 1996). The second category of knowledge is "knowledge" or called explicit knowledge where this knowledge is easier to explain and understand because it has been formed in information and data data. To compare the two categories, experts use the iceberg analogy (Ancori et al., 2000); (HaldinHerrgard, 2005). Explicit knowledge is part of the iceberg that appears on the surface of the sea. Meanwhile, tacit knowledge is a part that is not visible because it is carried by sea level (Nonaka \& Takeuchi, 1995).

For succession, the senior generation must transfer their knowledge. However, most of the knowledge they have is in the form of tacit knowledge. The method of transfer of tacit knowledge needs to be studied and further developed. Grant (2007) says that tacit knowledge possessed by the senior generation is derived from personal experience and is related to the development of skills, abilities and knowledge. Nonaka \& Takeuchi (1996) also explain that tacit knowledge is embedded in the personal experience of the senior generation which consists of intangible aspects such as trust, perspective, and value values. Besides that humans often acquire tacit knowledge unconsciously or have the intention to learn it. As a result, this situation makes it difficult for the senior generation to explain to the next generation.

Polanyi (1996) explains that both types of knowledge are actually related to each other where explicit knowledge has a tacit component. Thus, tacit knowledge can be supposed to be transferred to the next generation.

Business managers and academics have realized that tacit knowledge is the main source of competitive advantage (Competitive advantage) (Grant, 1997). In the business strategy literature, knowledge is a potential resource for companies. If the knowledge contains a tacit dimension, then that knowledge will produce characteristics that are valuable, rare, inimi- 
table and non-substitutable (Polanyi, 1966; Hall $\&$ Sapsed, 2005). Tacit knowledge is a source of unique abilities that are difficult for other companies to imitate. Tacit knowledge becomes a company's competitive competitiveness (McAulay et al., 1997). In short, the tacit knowledge of the senior generation contributes to the sustainability of the family company.

Determining the right transfer method is the main challenge for family business actors, especially first generation family companies. Grant (1996) explains that knowledge transfer requires an understanding of culture, processes, and stories between parties who have knowledge and those who will receive knowledge. Therefore, to do the transfer requires good cooperation through trust. Polanyi (1966) and Tsoukas (2002) explain that the transfer of knowledge in the effective tacit category consisted of two methods: (1) observation and (2) experience experiencing (Experiencing). Le Breton-Miller (2004) explains the transfer of tacit knowledge requires a fairly long process, starting from (1) dining table (informal situation) then continued, (2) summer/part time job on company (non-managerial) and continued again with, (3) the career of the next generation of the family company (involved in company managerial). The characteristics of tacit knowledge that are difficult to articulate, implicit, are embedded in one's personality and based on experience (Polanyi, 1966; Nelson \& Winter 1982) require different methods than the transfer of explicit knowledge and may be different for each family company.

\section{METHOD}

This study aims to examine the process of transfer of tacit knowledge in family companies in Surabaya. This study focuses on clarity when, how, and what tacit knowledge is transferred in the period before the transition of generations from the perspective of the senior generation and the next generation. In addition, this study also focuses on the reflection of the senior generation and future generations in the past process to answer research questions, namely how, when and what. This study uses case studies (Yin, 2003) to understand real-life phenomena in depth without ignoring contextual conditions (Yin, 2009). This research method allows researchers to obtain characteristics of the process of transfer of knowledge between generations to family enterprises as a whole (Yin, 2009). To avoid differences due to the scale of the company, this study chooses medium-scale family companies as the object of research. The selection is based on their capacity to answer research questions and their contributions in developing theories (Higginson, 2009). The criteria for selecting research objects are as follows: (1) two generations are involved in family companies, (2) family companies from the first generation are the companies built by the first generation, and the next generation refer to the first generation's biological children, (3) The company has stood at least 10 year.

The results of this study are expected to produce knowledge transfer methods that can be a reference for other family companies. However, the possibility of differences due to different cultural characteristics in each family is unavoidable. Data collection is done through in-depth interviews with the senior generation and the next generation of family companies. To ensure validity and credibility, this study uses several methods, namely respondent validation (member checking) and triangulation (Yin, 
Teddy Saputra / The First Generation's Tacit Knowledge Transfer /

JEE, Vol. 7, No. 2, September 2018, pp 95-104

2009; Creswell, 2010; Wahyuni, 2012). The triangulation used in this study is done through source triangulation.

\section{RESULTS AND DISCUSSION}

At the beginning of the study, the researcher conducted an interview involving 10 participants in 5 family companies in Surabaya (5 were the senior generation and the 5 next generation were biological children of the senior generation). This study found the knowledge transfer process that occurred in the five family companies. The transfer was made through a statement from the senior generation of GM companies that said, "As a family company owner, I hope my children will continue the company. I think everyone will do the same. Since childhood, I have often brought children to the office to see how and what I do. "A similar statement was also conveyed by the senior generation of SJ companies, "all parents who have businesses would want their children to continue the company. It's up to the child whether they want to continue or not. But, of course it will be in vain if no one continues the company". Other family companies also have the same opinion. This shows that the transfer of knowledge has been planned by the senior generation since the next generation is still a child. They hope their children want to continue the company.

When does the knowledge transfer process begin? The owner of GM companies states, "When I was a child, my father often invited me to come to the store and incidentally the store had an office where my father worked. At that time I was in junior high (aged 11 years) if I not wrong. I did not always come to that place since then, about a month and 4 times until I was in high school."
The next generation of GAKG companies says, "It happened when I was still a child (11 years old). I used to be invited to the project. There my father showed new houses. My father also introduced me to employees." The statements of the next generation show that the knowledge transfer process began when the next generation was still a child and continued until they were adults.

How is the transfer of tacit knowledge done? The senior generation of GM companies explains that "Transfer of knowledge occurs gradually. First I ask my child to come to the shop, factory. I ask him to pay attention to what and how employees work. Every night, or when having lunch, I ask about what he sees, he answers and I answer. The more he became big, the more I invited my child to the office. I introduced him to a friend of a business, and then I invited him to China to see the exhibition. There I asked what items were good for sale. Recently I gave him the position of director of finance. Furthermore, I planned to appoint him as director of store development as well, I gave him a challenge to continue learning “. The senior generation of the WL company explained, "I asked him to go to the restaurant, then I also asked him to go to the kitchen and to take care of the cashier. When my child became an adult he decided to study at culinary college. But he didn't want to and I asked him to go to business. I think this is the way I teach my children."

The observation technique is continued with experiencing techniques. This technique is done by inviting the next generation to the business location. After the next generation grows up, they are trained with different techniques. The GM company invites the next generation to go to exhibitions in China. This is because the GM company aims to buy products 
there. GAKG company owners bring children closer to senior employees. Meanwhile, the owner of the WL company gradually involved his child to take part in work in the restaurant company.

What are the tacit knowledge transferred to the next generation? The senior generation of GM companies explained "Initially before doing business, they have to learn how we do business. For example, children have to take care of their own health. They should not be sick. In addition to the child must always be healthy, he also must pay attention to others and do not be afraid of loss. If they see employees who need money, just give it to them. Then after the children understand, they need to learn business. He must be able to talk to other people, especially to our business partners in China, Japan and Europe. Children must learn the tricks of the trick. The owner of GAKG family company explained, "Calculations are important in my business. But it is not just a mathematical calculation, the calculation can be kind of". To dig deeper information, the author also asked questions to the next generation of each family company. The next generation of GM companies provides an explanation, "My father often tells me about how to negotiate. This negotiation can be done with our agents, our overseas vendors, employees. Then my father also teaches how to choose good products for our goods import business. I thought my father teaches me more, and my father is great."

The process of transfer of knowledge in family companies is divided into four stages: (a) initiation, (b) implementation, (c) ramp-up, (d) integration (Szulanski, 1996). Varamäki et al., (2003) explain 3 stages in the transfer of tacit knowledge. The first stage is known as "Getting to know the field (growing into entrepreneur- ship)" or understanding how to work. The second stage is: "Familiarization (actual stage of transferring knowledge)" or learn how to work and make what is known to be a habit. The last stage is: "The stage of independent development of the business (creating explicit and tacit knowledge)" or increasing the knowledge gained into new knowledge.

At the initiation stage, the participant's family company starts by inviting the next generation to the business location. This activity is carried out when the junior generation is still a child. The senior generation of GM companies explained that by taking him to a business location children could see the process of working, "making money" was the term delivered. At this stage the senior generation shows how they work and what efforts they want their child to continue. Garcia-Alverez et al., (2002) examined the pattern of socialization between generations in family companies and he said that the pattern consisted of two phases. In the first phase, the senior generation tends to provide knowledge about the values, norms and habits of the senior generation at work. This situation was demonstrated by an initiative in which GM family owners invited their children to visit the store while explaining how important it was to work on time, have discipline, have a willingness to share and empathize. The SJ family owner also asked his son to visit the store while showing how to assess and deal with customers. GAKG family company owners ask their children to come to the project while showing how the senior generation values its employees. The senior generation WL family company stressed "This is important to reduce consumption of food that our customers do not eat them up. There should be no waste. If our customers dispose food, this means they are not satisfied with our food". 
Teddy Saputra / The First Generation's Tacit Knowledge Transfer /

JEE, Vol. 7, No. 2, September 2018, pp 95-104

The second stage of the implementation phase. At this stage, both generations are aware of the knowledge transfer process. In this stage, the next generation has begun to grow up and has the ability to ask. Knowledge transfer activities have many variations. The owner of the GM family company invited his son to take part in a trade show in China, asking his son to take on the role of the cashier. The owner of the company encourages their children to ask questions and argue. The owner of the GAKG family company begin to give his child the task of offering a home. Garcia-Alverez et al., (2002) explained that in the second phase, the senior generation began to provide knowledge about the business with their involvement. According to Varamäki et al., (2003) at this stage there is a process called "Familiarization (actual stage of transferring knowledge)". The situation is shown by the existence of question and answer and more intensive discussions between the senior generation and the next generation.

The third stage is known as ramp up. This stage begins when the successor uses the knowledge he has learned. At this stage the senior generation gives delegates to their children to learn to make decisions in business. The GAKG family company gives trust to their children to join the company's marketing team and is responsible for a number of sales. GM companies give trust to the next generation of products to resell. Although during its work the senior generation asked an employee to trust him to assist the next generation. At this stage, the senior generation began to provide knowledge about the business run by the company. This is called business competence. Chirico (2007) mentions that there are 3 business competencies inherent in senior generation tacit knowledge, namely (1) "Industry-related competences", are compe- tencies related to the family business business industry, (2) "Business competences", which are technical competencies and skills in managing a family company and, (3) "Ownership competences", are competencies related to the attitude of a company owner.

The fourth stage is called integration. At this stage, the next generation has more and more tasks and responsibilities. The senior generation of WL companies gives responsibility to their children to manage one branch. With this task and responsibility the next generation of WL companies face different challenges. "The challenges are certainly different. I am currently facing various problems that sometimes I actually do not understand how to solve them. However, my father said that if there was a problem despite a small problem he asked me to discuss with my father before deciding ". The same experience was experienced by the next generation of GM companies that were given responsibility as business development directors who were responsible for managing branches and expanding branches of the company. "I have to discuss with my father first before making a decision. I always consider my father's opinion. This is a learning process “

According to Varamäki et al. (2003) this stage of interaction is, "The stage of independent development of business (creating new and explicit knowledge)." At this stage the collaboration between the senior generation and the next generation is not only related to the acceptance of knowledge from the senior generation but also occurs meeting between senior generation knowledge and the knowledge of future generations. Thus, explicit or tacit knowledge is obtained. The next generation of WL companies issued a program "Share the two foods" intended for customers who come together with 
parents who are over 60 years old. "I issued this program for those who want to share with their elderly papa or mama. Actually, I only reduced the portion of the parents and then I discounted because often I see people over 60 like to leave their food".

During the interview, the authors found that the role of trust turned out to have a significant impact on the successful transfer of tacit knowledge. The author suggests further research on the role of trust in family companies, especially in the diffusion of knowledge. This belief is seen when the senior generation invites the next generation to follow up. It seems clear that good relations (relationships within the family) help this process of knowledge transfer. Coleman (1998) calls it as social capital.

\section{CONCLUSION}

The generation process is said to be successful if the next generation has gained legitimacy and is widely accepted by corporate stakeholders (Tatoglu et al., 2008). This study explains how family companies in Surabaya transfer tacit knowledge. This research confirms several important points: (1) the transfer of knowledge does not have a time limit. According to the senior generation, the end time limit is the time when they cannot work anymore. (2) Knowledge transfer has impacts on the next generation (3) and determines the success of knowledge transfer. The involvement of trust needs to be investigated and further developed. For further research, researcher suggests next researchers to consider the importance of expanding the number of participants and involving other variables such as gender and ethnicity.

\section{REFERENCES}

Ancori, B., Bureth, A., \& Cohendet, P. 2000. The Economics of Knowledge: The Debate About Codification And Tacit Knowledge. Journal Industrial and Corporate Change, Vol. 9.

Chirico, F. 2007. The Accumulation Process of Knowledge in Family Firms. Electronic Journal of Family Business Studies, 1(1), 62-90.

Chirico, F. 2008. The Creation, Sharing, and Transfer of Knowledge in Family Business. Journal of Small Business \& Entrepreneurship, Vol. 4, 413-434.

Creswell, J. 2010. Qualitative Inquiry and Research Design: Chosing among Five Approach. University of Nebraska, Lincoln: SAGE Publication Ltd.

Coleman, J. 1998. Social Capital in the Creation of Human Capital. American Journal of Sociology, Vol. 94, 95-120.

Davenport, T. \& Prusak, L. 1998. Working Knowledge. Cambridge, MA: Harvard University Press.

Fox, M., Nilakant, V., \& Hamilton, R.T. 1996. Managing Succession in Family-Owned Businesses. International Small Business Journal, 15(1), 15-25.

Frank, H., Lueger, M., Nose, L., \& Suchy, D. 2010. The Concept of "Familiness": Literature Review and Systems Theory-based Reflections. Journal of Family Business Strategy, 1(3), 119-130.

Gardner, H. 1995. Reflections on Multiple Intelligences: Myths and Messages. Phi Delta Kappan, Vol.77, 200-203, 206-209.

Garcia Alvarez, E., Lopez Sintas, J., \& Gonzalvo. 2002. Socialization Patterns of Successors in First to Second Generation Family Busi- 
Teddy Saputra / The First Generation's Tacit Knowledge Transfer /

JEE, Vol. 7, No. 2, September 2018, pp 95-104

nesses. Family Business Review, 15(3), 189-200.

Gersick, K.E., Davis. 1997. Generation to Generation: Life Cycles of the Family Business. Boston, MA: Harvard Business School Press.

Grant, R.M. 1996. Toward a Knowledge based Theory of the Firm. Strategic Management Journal, 17(Special Issue), 109220.

Grant, R.M. 1997. The Knowledge-based View of the Firm: Implications for Management Practice. Long Range Planning, 30 (3), 450-460.

Grant, R.M. 2007. Relational Job Design and the Motivation to Make a Prosocial Difference. Academy of Management Review, Vol. 32, 393-417.

Haldin-Herrgard, T. 2005. Difficulties in Diffusion of Tacit Knowledge in Organizations. Journal of Intellectual Capital. 1(4), 357367.

Hall, J. \& Sapsed, J. 2005. Influences of Knowledge Sharing and Hoarding in Projectbased Firms. Management of Knowledge in Project Environments, ButterworthHeinemann, Oxford, 57-79.

Hall, J., Anika, \& Mattias Nordqvist. 2008. Professional Management in Family Businesses: toward an Extended Understanding. Family Business Review, 21(1), 51-68.

Higginson, N. 2009. Preparing the Next Generation for the Family Business: Relational Factors and Knowledge Transfer in Mother - to Daughter Sucession. Journal of Management and Marketing Research, 1-18.

Lambrecht, J. 2005. Multigenerational Transition in Family Businesses: A New Explanatory Model. Family Bus. Rev., 18(4):267-283.
Le Breton-Miller, I., Miller, D., \& Steier, L.P. 2004. Towards an Integrative Model of Effective FOB Succession. Entrepreneurship Theory \& Practice, 28(4), 305-328.

Lee, J. 2006. Family Firm Performance: Further Evidence. Family Business Review, 19(3), 103-114. http://dx.doi.org/10.1111/j.17416248.2006.00060.x

Nelson, R. \& Winter S. 1982. An Evolutionary Theory of Economic Change. Harvard University Press, USA.

Nonaka, I. \& Takeuchi, H. 1995. The Knowledge-Creating Company: How Japanese Companies Create the Dynamics of Innovation. Oxford University Press.

Nonaka, I. \& Takeuchi H. 1996. The Knowledge-Creating Company. New York: Oxford University Press.

McAulay, L., Russell, G., \& Sims, J. 1997. Tacit Knowledge for Competitive Advantage. Management Accounting, 75(11), 36-38.

Polanyi, M. 1966. The Tacit Dimension. London: Routledge \& Kegan Paul Ltd.

Szulanski, G. 1996. Exploring Internal Stickiness: Impediment to the Transfer of Best Practicess within the Firm. Strategic Management Journal, 17, 27-43.

Tatoglu, E., Kula, V., \& Glaister, K.W. 2008. Sucession Planning in Family - Owned Business: Evidence from Turkey. International Small Business Journal, 26, 155.

Trevinyo-Rodriguez, R.N. \& Tapies, J. 2006. Effective Knowledge Transfer in Family Firms. In: P.Z. Poutziouris., K.X. Smyrnios., \& S.B. Kein. Handbook of Research on Family Bussines. Cheltenham, pp. 343357. UK: Edwar Elgar Publishing Limited.

Tsoukas, H. 2002. Do We Really Understand Tacit Knowledge? Paper Presented at the 
Knowledge Economy and Society Seminars. LSE Department of Information Systems.

Varamäki, E., Pihkala, T., \& Routamaa, V. 2003. Stages of Transferring Knowledge in Small Family Business Successions. Paper Presented at the Proceedings of Family Business Network 14th Annual World Conference.

Wahyuni, S. 2012. Qualitative Research Method: Theory and Practice. Jakarta: Penerbit Salemba Empat.

Wayne, W., Irava., \& Ken, M. 2010. Resources Supporting Entrepreneurial Orientation in Multigenerational Family Firms. Interna- tional Journal of Entrepreneurial Venturing, 2 (3), 222-245.

Weggeman, M. 1997. Kennismanagement Inrichting en Besturing van Kennisintensieve Organisaties. Schiedam: Scriptum.

Yin, R.K. 2003. Case Study Resarch Design and Method, Third Edition. Thousand Oaks, California: Sage Publication, Inc.

Yin, R.K. 2009. Case Study Research. Thousand Oaks, California: Sage Publication, Inc.

Zellweger, T., Kellermanns, F., \& Eddleston, K. 2010. Exploring the Entrepreneurial Behavior of Family Firms: Does the Stewardship Perspective Explain Differences? Baylor University. 
Teddy Saputra / The First Generation's Tacit Knowledge Transfer /

JEE, Vol. 7, No. 2, September 2018, pp 95-104 